\title{
TINGKAT AKTIVITAS FISIK MAHASISWA PROGRAM STUDI PENDIDIKAN DOKTER TAHUN KEDUA, KETIGA, KEEMPAT
}

\author{
Yhusi Karina Riskawati ${ }^{\star 凶}$, Edwin Damar Prabowo**, Harun Al Rasyid ${ }^{* \star *}$
}

\begin{abstract}
Abstrak
Penyakit tidak menular merupakan pembunuh nomor satu di dunia hari ini. Salah satu penyebab terjadinya penyakit tidak menular ialah kekurangan aktivitas fisik. Mahasiswa kedokteran sebagai dokter di masa mendatang diharapkan dapat menjadi teladan dan memberikan konsultasi yang baik tentang aktivitas fisik kepada pasiennya sehingga mahasiswa kedokteran perlu memiliki aktivitas fisik yang baik. Tujuan dari penelitian ini adalah untuk mengetahui tingkat aktivitas fisik mahasiswa Program Studi Pendidikan Dokter, Fakultas Kedokteran Universitas Brawijaya dan pengaruh usia, jenis kelamin, kondisi tempat tinggal, aktivitas organisasi/kepanitiaan dan tingkat pengetahuan terhadap tingkat aktivitas fisik tersebut. Penelitian observasional ini menggunakan desain cross-sectional. Sampel diambil secara purposive sampling sebanyak 90 orang responden mahasiswa Program Studi Pendidikan Dokter FK UB tahun 2014 - 2016 yang memasuki tahun pendidikan kedua, ketiga dan keempat. Data usia, jenis kelamin, kondisi tempat tinggal, aktivitas organisasi/kepanitiaan, tingkat pengetahuan dan aktivitas fisik dikumpulkan menggunakan kuesioner yang telah diuji validitas dan reliabilitas. Aktivitas fisik diukur menggunakan kuesioner standar GPAQ (Global Physical Activity Questionnaire) oleh WHO. Analisis data menggunakan uji chi square. Dari hasil analisis didapatkan $60 \%$ responden memiliki aktivitas fisik yang rendah. Faktor usia $(p=0,194)$, jenis kelamin $(p=0,323)$, kondisi tempat tinggal $(p=0,605)$, tingkat pengetahuan $(p=0,839)$ dan aktivitas organisasi/kepanitiaan $(p=0,293)$ tidak memiliki pengaruh yang signifikan terhadap tingkat aktivitas fisik mahasiswa Program Studi Pendidikan Dokter FKUB tahun kedua, ketiga dan keempat angkatan tahun 2014 $-2016$.
\end{abstract}

Kata kunci: mahasiswa program studi pendidikan dokter, tingkat aktivitas fisik.

\section{PHYSICAL ACTIVITY LEVEL OF THE SECOND, THIRD, AND FOURTH YEARS STUDENTS AT STUDY PROGRAM OF MEDICINE}

\begin{abstract}
Non-communicable diseases are the number one killer in the world today. One of the causes is a person's lack of physical activity. As a future doctor, medical students are expected to be role models and provide good consultation on physical activity to their patients, therefore medical students need to have good physical activity. The purpose of this study was to determine the physical activity level of medical students in Faculty of Medicine Universitas Brawijaya and the effect of age, sex, living condition, organizational activity, and knowledge level to the level of physical activity. It was an observational study using cross sectional approach with purposive sampling method on 90 medical students of Faculty of Medicine of Universitas Brawijaya from second to fourth grade on year 2014 to 2016. The data of age, sex, level of knowledge, living condition, organizational/project activities are collected by questionnaire that have been test for its validity and reliability. Physical activity level is measured by GPAQ (Global Physical Activity Questionnaire) of WHO. The Chi square test was used to analysed hypothesis. It was found that $60 \%$ of respondents have low physical activity level. The age $(p=0.194)$, sex $(p=0.323)$, living condition $(p=0.605)$, knowledge $(p=$ $0.839)$ and organizational/project activities $(p=0.293)$ did not have significant effect on physical activity level of FKUB students from second to fourth grade on year 2014 to 2016.
\end{abstract}

Keywords: students of study program of medicine, physical activity level.

* Departemen Fisiologi, Fakultas Kedokteran Universitas Brawijaya

** Jurusan Pendidikan Dokter, Fakultas Kedokteran Universitas Brawijaya

${ }^{* * *}$ Departemen IImu Kesehatan Masyarakat, Fakultas Kedokteran Universitas Brawijaya

${ }^{凶}$ E-mail: yhusi@yahoo.com 


\section{Pendahuluan}

Non-communicable disease (Penyakit Tidak Menular) seperti penyakit kardiovaskular, kanker, dan diabetes merupakan pembunuh nomor 1 di dunia. ${ }^{1,2}$ Dari 57 juta orang yang meninggal di dunia setiap tahunnya, sebanyak $63 \%$ meninggal akibat penyakit tidak menular, yaitu 36 juta orang dan $80 \%$ terjadi di negara berpendapatan rendah dan berkembang. ${ }^{1}$ Kemenkes RI (2013) menyebutkan bahwa di Indonesia angka kejadian penyakit tidak menular terus meningkat setiap tahunnya. ${ }^{3}$

Salah satu faktor risiko utama penyakit-penyakit tersebut adalah gaya hidup sedentary yang meningkatkan mortalitas semua jenis penyakit termasuk melipatgandakan faktor risiko penyakit kardiovaskuler dan diabetes. ${ }^{2,4,5}$ Perkembangan teknologi makin meningkatkan jumlah populasi dan rentang usia yang melakukan gaya hidup sedentary. 4 Orang dengan sedentary lifestyle sering mengabaikan aktivitas fisik atau melakukan kegiatan yang tidak membutuhkan banyak energi. Aktivitas fisik yang rendah akan meningkatkan risiko seseorang sebesar 20 $30 \%$ terkena penyakit tidak menular tersebut dibanding orang dengan aktivitas fisik yang cukup yaitu sebesar 150 menit per minggu. ${ }^{5}$

Mahasiswa kedokteran sebagai calon tenaga kesehatan di masa mendatang diharapkan dapat menjadi teladan di lingkungannya dan mampu mempromosikan aktivitas fisik kepada setiap pasiennya. ${ }^{6}$ Namun, penelitian yang dilakukan oleh Utomo di Universitas Sebelas Maret, yang mendapatkan $\quad 15,24 \% \quad$ mahasiswa kedokteran memiliki tingkat aktivitas fisik yang rendah dan sebesar $50,47 \%$ memiliki tingkat aktivitas fisik yang sedang. ${ }^{7}$

Tingkat aktivitas fisik dapat dipengaruhi oleh yang tidak dapat dimodifikasi meliputi usia, jenis kelamin, ras, etnis dan faktor yang dapat dimodifikasi meliputi karakteristik individu, dukungan sosial, lingkungan tempat tinggal, status ekonomi, pekerjaan, keterbatasan fisik, level pendidikan/pengetahuan dan kesempatan mengakses pelayanan kesehatan. Mahasiswa Program Studi Pendidikan Dokter, Fakultas Kedokteran Universitas Brawijaya (FK UB) berasal dari berbagai wilayah di Indonesia dengan variasi karakteristik usia dan dukungan kondisi lingkungan tempat tinggal yang dapat mempengaruhi tingkat aktivitas fisiknya.

Program Studi Pendidikan Dokter di FKUB juga menerapkan kurikulum longitudinal yang padat berupa kuliah, diskusi, ketrampilan klinik, praktikum hingga ujian yang sebagian besar dilaksanakan dalam posisi duduk dalam waktu yang lama pagi hingga petang yang dapat berbeda dengan fakultas kedokteran lainnya. ${ }^{8}$

Selain itu, juga terdapat berbagai kegiatan kemahasiswaan yang dapat menyita waktu luang dan mempengaruhi tingkat aktivitas fisik. Selama memasuki masa kuliah, maka tingkat pengetahuan tentang kesehatan akan semakin meningkat sehingga menarik untuk diteliti, apakah faktor usia, jenis kelamin, kondisi lingkungan tempat tinggal dan tingkat pengetahuan dapat mempengaruhi tingkat aktivitas fisik mahasiswa Program Studi Pendidikan Dokter. Penelitian ini bertujuan untuk mengetahui tingkat aktivitas fisik mahasiswa Program Studi Pendidikan Dokter FK UB dan faktor-faktor yang mempengaruhinya.

\section{Bahan dan Metode}

Penelitian observasional ini menggunakan rancangan cross sectional. Sampelnya adalah mahasiswa Program Studi Pendidikan Dokter FK UB angkatan tahun 2014 - 2016 berjumlah 90 orang dengan menggunakan teknik purposive sampling. Seluruh responden memenuhi kriteria inklusi yaitu tidak memiliki cacat fisik 
yang dapat mengganggu aktivitas fisik dan tidak termasuk kriteria eksklusi yaitu tidak mengisi kuisioner dengan lengkap.

Variabel dalam penelitian ini adalah usia, jenis kelamin, kondisi tempat tinggal (mendukung yaitu memiliki fasilitas yang dapat memotivasi untuk melakukan olahraga/aktifitas fisik atau tidak mendukung aktivitas fisik), tingkat aktivitas organisasi/kepanitiaan yaitu jumlah hari dan dalam seminggu pada satu bulan terakhir mengurus kegiatan organisasi/ kepanitiaan dan tingkat pengetahuan yang diambil dengan menggunakan kuesioner yang dikembangkan oleh peneliti dan telah di lakukan uji validitas (nilai $r$ hitung antara 0,48 - 0,922 lebih besar dari $r$ tabel 0,44) dan reliabilitas (koefisien reliabilitas alpha > $0,743-0,789$ ) sebelumnya. Aktivitas fisik diukur dengan kuesioner standar WHO GPAQ (Global Physical Activity Questionnaire). Sebelum dilakukan penelitian, responden menandatangani informed concent sesuai surat keterangan kelaikan etik No. 253/EC/KEPK-S1PD/07/2017.
Analisis yang digunakan penelitian ini adalah analisis deskriptif untuk mengetahui karakteristik responden dan uji chi-square untuk mengetahui adanya pengaruh faktor usia, jenis kelamin, kondisi tempat tinggal (mendukung atau tidak mendukung aktivitas fisik), tingkat aktivitas organisasi/kepanitiaan, dan tingkat pengetahuan terhadap tingkat aktivitas fisik responden.

Hasil

Pada Tabel 1 menunjukkan rata-rata usia responden adalah 19,5 $\pm 1,03$ tahun, didominasi dari kelompok usia 19 tahun $(33,33 \%)$ dan 20 tahun $(33,33 \%)$, jenis kelamin perempuan $(64,44 \%)$ dan kelompok responden dengan kondisi tempat tinggal cukup mendukung (40\%). Mayoritas responden memiliki aktivitas organisasi yang cukup $(52,22 \%)$, tingkat pengetahuan yang sedang $(63,33 \%)$ dan tingkat aktivitas fisik yang rendah $(60 \%)$.

Tabel 1. Karakteristik mahasiswa Program Studi Pendidikan Dokter FK UB angkatan tahun 2014 2016

\begin{tabular}{lccc}
\hline Karakteristik Responden & Kategori & Jumlah (n) & Persentase (\%) \\
\hline Usia & 17 & 3 & 3,33 \\
& 18 & 7 & 7,78 \\
& 19 & 30 & 33,33 \\
& 20 & 30 & 33,33 \\
& 21 & 17 & 18,89 \\
& 22 & 3 & 3,33 \\
\hline Jenis Kelamin & Laki - Laki & 32 & 35,56 \\
& Perempuan & 58 & 64,44 \\
\hline Kondisi Tempat Tinggal & Tidak Mendukung & 20 & 22,22 \\
& Cukup Mendukung & 36 & 40 \\
& Mendukung & 34 & 37,78 \\
\hline Aktivitas Organisasi & Kurang & 11 & 12,22 \\
& Cukup & 47 & 52,22 \\
& Aktif & 32 & 35,56 \\
\hline Tingkat Pengetahuan & Rendah & 21 & 23,33 \\
& Sedang & 57 & 63,33 \\
& Tinggi & 12 & 13,33 \\
\hline Aktivitas Fisik & Rendah & 54 & 60 \\
& Sedang & 32 & 35,56 \\
& Tinggi & 4 & 4,44 \\
\hline
\end{tabular}


Pada Tabel 2 diketahui bahwa usia, jenis kelamin, kondisi tempat tinggal, aktivitas organisasi dan tingkat pengetahuan tidak memiliki pengaruh yang signifikan terhadap tingkat aktivitas fisik.

Tabel 2. Pengaruh variabel terhadap tingkat aktivitas fisik responden

\begin{tabular}{lc}
\hline \multicolumn{1}{c}{ Variabel } & Nilai p \\
\hline Usia & 0,194 \\
Jenis Kelamin & 0,323 \\
Kondisi Tempat Tinggal & 0,605 \\
Aktivitas Organisasi & 0,293 \\
Tingkat Pengetahuan & 0,839 \\
\hline
\end{tabular}

\section{Pembahasan}

Hasil penelitian ini menunjukkan bahwa $60 \%$ mahasiswa kedokteran memiliki aktivitas fisik yang rendah. Hasil ini berbeda dengan penelitian yang dilakukan pada mahasiswa Fakultas Kedokteran Universitas Udayana, yaitu terdapat $38,3 \%$ mahasiswa memiliki tingkat aktivitas fisik yang rendah dan $61,6 \%$ mahasiswa memiliki tingkat aktivitas fisik yang sedang-tinggi. ${ }^{9}$ Keadaan ini dapat terjadi karena perbedaan kurikulum yang diterapkan pada masing-masing fakultas kedokteran dalam mencapai kompetensinya. Kemungkinan terdapat faktor stres akibat kegiatan akademik dan non-akademik yang terjadi di FK UB. Seperti yang dinyatakan oleh Koeneman et al. (2011) menyatakan bahwa stres merupakan faktor penentu dari tingkat aktivitas fisik seseorang, namun variabel stres sendiri tidak dibahas pada penelitian ini.

Faktor usia diketahui tidak memiliki pengaruh yang signifikan terhadap tingkat aktivitas fisik karena perilaku aktivitas fisik sangat tergantung pada kebiasaan yang telah ditanamkan sebelumnya. Penelitian yang dilakukan oleh Telama et al. (2005) pada anak usia sekolah dan usia dewasa muda menunjukkan bahwa usia dan aktivitas fisik memiliki hubungan korelasi yang rendah ke sedang. Namun, pada penelitian ini diketahui bahwa usia dan aktivitas fisik memiliki korelasi yang rendah. Meskipun demikian, apabila aktivitas fisik tersebut secara rutin dilakukan sejak kecil, maka dapat meningkatkan kemungkinan seorang memiliki aktivitas fisik yang cukup saat dewasa. ${ }^{10}$

Selain itu, jenis kelamin juga diketahui tidak memiliki pengaruh terhadap tingkat aktivitas fisik. Hasil ini dapat terjadi karena responden berjenis kelamin laki-laki ataupun perempuan memiliki kegiatan akademik yang hampir sama selama menjalani kuliah.

Hasil penelitian ini menggambarkan bahwa lebih dari $60 \%$ mahasiswa Program Studi Pendidikan Dokter Universitas Brawijaya tinggal di tempat yang tidak cukup mendukung untuk melakukan aktivitas fisik. Hal ini dapat terjadi akibat padatnya pemukiman di Kota Malang khususnya di sekitar Universitas Brawijaya, kurang baiknya kebijakan pemerintah mengenai tata kota, dan kurangnya kesadaran dalam pemanfaatan fasilitas sekitar untuk aktivitas fisik. Hal ini bertentangan dengan pernyataan WHO bahwa tempat tinggal selayaknya memliki lingkungan yang baik bagi kesehatan jasmani dan rohani, serta keadaan sosial yang baik untuk kesehatan keluarga dan kesehatan individu. ${ }^{5}$ Namun, kondisi tempat tinggal ini ternyata tidak memiliki pengaruh terhadap tingkat aktivitas fisik. Berbeda dengan hasil penelitian Owen et al. yang dilakukan pada orang usia dewasa, yaitu tempat tinggal dalam konteks lokasi tempat rekreasi dan walkabilty sekitar tempat tinggal memiliki hubungan dengan tingkat aktivitas fisik. ${ }^{11}$

Keikutsertaan mahasiswa dalam aktivitas organisasi $(52,22 \%)$ tidak memiliki pengaruh yang signifikan terhadap tingkat aktivitas fisik. Berbeda dengan penelitian 
terdahulu oleh Kirk dan Rhodes bahwa total jam kerja dan waktu lembur memliki hubungan terbalik dengan total aktivitas fisik yang dilakukan pada waktu luang. ${ }^{12}$

Mahasiswa Program Studi Pendidikan Dokter Universitas Brawijaya diketahui memiliki tingkat pengetahuan sedang hingga tinggi $(78,66 \%)$. Hal ini sesuai dengan Standar Kompetensi Dokter Indonesia (SKDI), yaitu mahasiswa kedokteran diwajibkan untuk mempelajari pencegahan penyakit tidak menular. Walaupun pengetahuan tidak memiliki pengaruh yang signifikan terhadap tingkat aktivitas fisik. Penelitian terdahulu oleh Bauman et al. dan Sallis et al. menyatakan bahwa pengetahuan indvidu memiliki hubungan positif dengan tingkat aktivitas fisik seseorang. ${ }^{13,14} \mathrm{Hal}$ ini dapat terjadi karena terdapat faktor-faktor individual yang mempengaruhi transformasi pengetahuan menjadi suatu perilaku yang positif yang belum diteliti. Salah satunya adalah faktor barrier internal diantaranya merasa terlalu lelah, sudah merasa aktif, dan kurang motivasi. ${ }^{15}$

Ahli promosi kesehatan mencoba menjelaskan beberapa konsep mengenai faktor individu yang dapat mempengaruhi motivasi dan kepercayaan diri sehingga dapat berpengaruh terhadap kesehatan seseorang, yaitu konsep Self-Efficacy (SE) oleh Bandura dalam teori Social Cognitive Theory dan konsep Sense of Coherence (SOC) oleh Antonovsky dalam teori Salutogenic. Konsep ini menjelaskan bahwa semakin tinggi self-efficacy, maka semakin tinggi pula tingkat perilaku sehatnya. Bodenheimer menyatakan bahwa SelfEfficacy adalah variabel yang dapat mempengaruhi status kesehatan, mood dan motivasi yang akan menentukan tingkah laku kesehatan. ${ }^{16}$ Seseorang yang memiliki nilai SOC tinggi lebih mudah untuk melakukan aktivitas terkait kesehatan yang bersifat positif dan baik untuk meningkatkan kualitas hidupnya, serta mengurangi kegiatan yang dapat menggangu kesehatan seperti mengonsumsi alkohol. ${ }^{17}$

\section{Kesimpulan}

Penelitian ini menyimpulkan bahwa tingkat aktivitas fisik mahasiswa kedokteran tergolong rendah $(60 \%)$. Faktor usia, jenis kelamin, kondisi tempat tinggal, aktivitas organisasi, dan tingkat pengetahuan tidak memiliki pengaruh yang signifikan terhadap tingkat aktivitas fisik.

\section{Saran}

Penelitian lebih lanjut perlu dilakukan untuk menggali pengaruh faktor-faktor lain seperti faktor psikososial individu yang mempengaruhi motivasi, tingkat stres sebagai mahasiswa, faktor interpesonal, faktor lingkungan dan faktor kebijakan yang juga dapat berperan sebagai determinan utama tingkat aktivitas fisik mahasiswa Program Studi Pendidikan Dokter FK UB.

Penanganan kurangnya aktivitas fisik yang terjadi pada mahasiswa Program Studi Pendidikan Dokter FK UB perlu melibatkan institusi dan organisasi mahasiswa. Edukasi tentang pentingnya aktivitas fisik dalam pencegahan penyakit tidak menular kepada mahasiswa terutama yang aktif berorganisasi/kepanitiaan perlu dilakukan secara berkesinambungan. Pembelajaran tentang topik pencegahan penyakit tidak menular khususnya terkait aktivitas fisik perlu ditingkatkan. Salah satunya dapat difasilitasi melalui Mata Kuliah Kedokteran Keluarga yang terintegrasi dalam Mata Kuliah IImu Kedokteran Masyarakat.

Kebijakan atau kegiatan yang dapat mendorong para aktivis organisasi/ kepanitiaan untuk tetap dapat melakukan aktivitas fisik secara teratur perlu mendapatkan dukungan. 


\section{Daftar Pustaka}

1. (WHO) World Health Organization. 10 Facts on Noncommunicable Diseases. (Online).2013.http://www.who.int/features /factfiles/noncommunicable_diseases/en/

2. (WHO) World Health Organization. Global Status Report on Noncommunicable Diseases. (Online). 2014. http://www.who.int/nmh/publications/ncdstatus-report-2014/en/.

3. Kementeerian Kesehatan Republik Indonesia. Riset kesehatan dasar. Jakarta: Badan Penelitian dan Pengembangan Kesehatan. (Online). 2013.

http://www.depkes.go.id/resources/downl oad/general/Hasil\%20Riskesdas $\% 20201$ 3.

4. (WHO) World Health Organization. Physical Inactivity a Leading Cause of Disease and Disability, Warns WHO. (Online). 2002. http://www.who.int/mediacentre/news/rel eases/release23/en/.

5. (WHO) World Health Organization. Global Action Plan for The Prevention and Control of Noncommunicable Diseases: 2013-2020.

(Online).2013.http://www.who.int/nmh/ev ents/ncd action plan/en/.

6. Seefeldt V, Malina RM, Clark MA. Factors Affecting Levels of Physical Activity in Adults. Sports Medicine. 2002; 32(3):143-68.

7. Utomo HS. Hubungan Aktivitas Fisik dengan Kapasitas Memori Kerja pada Mahasiswa Program Studi Kedokteran Universitas Sebelas Maret. Surakarta: Universitas Sebelas Maret. 2015.

8. Kedokteran PSS. Buku Pedoman Akademik. Malang: Fakultas Kedokteran Universitas Brawijaya. 2017.

9. Habut MY, Nurmawan IPS, Wiryanthini IAD. Hubungan Indeks Massa Tubuh dan
Aktivitas Fisik terhadap Keseimbangan Dinamis pada Mahasiswa Fakultas Kedokteran Universitas Udayana. Majalah IImiah Fisioterapi Indonesia. 2016; 2(1).

10. Telama R, Yang X, Viikari J, Valimaki I, Wanne O, Raitakari O. Physical Activity from Childhood to Adulthood: A 21-Year Tracking Study. American Journal of Preventive Medicine. 2005; 28(3):267-73.

11. Owen N, Humpel N, Leslie E, Bauman A, Sallis JF. Understanding Environmental Influences on Walking; Review and Research Agenda. American Journal of Preventive Medicine. 2004; 27(1):67-76.

12. Kirk MA, Rhodes RE. Occupation Correlates of Adults' Participation in Leisure-Time Physical Activity: A Systematic Review. American Journal of Preventive Medicine. 2011; 40(4):476-85.

13. Bauman AE, Reis RS, Sallis JF, Wells JC, Loos RJ, Martin BW. Correlates of Physical Activity: Why are Some People Physically Active and Others Not?. Lancet. 2012; 380(9838):258-71.

14. Sallis JF, Prochaska JJ, Taylor WC. A Review of Correlates of Physical Activity of Children and Adolescents. Medicine and Science in Sports and Exercise. 2000; 32(5):963-75.

15. Victor CR, Rogers $A$, Woodcock $A$, Beighton C, Cook DG, Kerry SM, et al. What Factors Support Older People to Increase Their Physical Activity Levels? An Exploratory Analysis of The Experiences Of PACE-Lift Trial Participants. Archives of Gerontology and Geriatrics. 2016; 67:1-6.

16. Bodenheimer $\mathrm{T}$, Lorig $\mathrm{K}$, Holman $\mathrm{H}$, Grumbach K. Patient Self-Management of Chronic Disease in Primary Care. JAMA. 2002; 288(19):2469-75.

17. Saravia JC, Iberico $C$, Yearwood K. Validation of Sense of Coherence (SOC) 13-Item Scale in A Peruvian Sample. 
Journal of Behavior, Health and Social Issues. 2014; 6(2):35-44. 